\title{
Study of Nonformal and Informal Education Policy Toward Professionalism Education Services for Community
}

\author{
Y.Shantini, E. S. Permana \\ Departemen Pendidikan Luar Sekolah \\ Universitas Pendidikan Indonesia \\ Bandung, Indonesia \\ yanti.shantini@gmail.com
}

\begin{abstract}
Government responsibility in advancing education, was supported by policy and regulation to encourage professional work of education services that serve by formal and non-formal way. In reality capability to implement the policy or regulation still has problem which is become obstacle to enlarge education services to community. This research aims to analyze the supervisors, managers and institutional of nonformal education in every role, which relating with duties and their obligation in nonformal education units. Subject in this research are managers of Community Learning Center (CLC) and Smart House (SH) to get available data with open questionnaire and interview as a data collection tool. Results of the study are policies and regulations set by the government has been known by the managers of the units in community only in the implementation, the cultivated not been fully implemented due to limitations in the knowledge and ability of the institution. As to follow up we need a mechanism for dissemination policies and regulations set by the government with the involvement of stakeholders, namely inspector and local governments to be able to follow up the implementation of of these rules in order to produce professional education services
\end{abstract}

Keywords_Policy; Units; Managers;

\section{INTRODUCTION}

Nonformal education appears because implementation of formal education not been able to generate competent graduates in this era. Graduates school education does not guarantee someone to have a good job's. Graduates school education should try to get a good job, but most of them feel ashamed to work, which is not in accordance with the respective fields and its increase's unemployement.

Based on limited observation researchers showed that managers of Community Learning Center and Smart House should be able to implement their task and function but in the fact, they are not fully understood with their task and function to relate on policy and regulation of government. Actually, managers of Community Learning Center and Smart House can be the main facilitator to implement the policy and regulation of government.

Some of nonformal education units being an organizer of education, there are Community Learning Center, Institution Courses and Training, Early Chilhood and Education and other similar units. That institution is place and media to society service-learning activities, which can be alternative as formal education replacement. Currently, most of the nonformal education units with range of program relating the old units.

Focus of this research is managers of nonformal education in nonformal education institution, especially Community Learning Center, Smart House and Study Group. This research is relating task and function of managers, supervisor and institution of nonformal education as in policy and regulation of government. Because fact in the field the policy and regulation from Government haven't been running properly.

\section{LITERATURE REVIEW}

\section{A. Essence Of Nonformal Education Services}

It defines education services it begins with discussions of nonformal education basic concept. The terms of implementation of nonformal education have been addressed in Act number 20th of 2003 on the national education system. Implementation of non-formal education is conducted to provide educational services to society that might not get the service on school education and be lifelong education service access. The purpose of nonformal education itself is expanding, leveling, and improve the quality of early-childhood education services, basic education, education for society, educational skills for women and continuing education. In addition, nonformal education also aims to organize a quality workforce either manager or facilitator and enhance public participation as well as local governments.

The Organization of non formal education itself aims to build a nation, so that programs which implemented adapted to the needs of nation. The programs implemented to help development programs, including Early-Childhood Education, Program Equivalence, Program For Eradication Of Illiteracy, Program to raise community reading interest, Women's Education Programs, Continuing Education Programs, Program Development And Empowerment Community And Learning Activities Center.

\section{B. Juridical Foundation In Organizing Nonformal Education}

The following researchers cite several juridical foundations relating to the organization of nonformal education including Act No. 20 of 2003 on the national education systems, 
Government regulation number 17 in 2010 about management education and conducting education, Regulation of the Minister of education and culture number 812013 about establishment of nonformal education institution, Government Regulation No. 32 2013 About education standards.

\section{Community Based-Education}

According to Ajat Sudrajat journal, education essentially has two objectives, namely helping people to be intelligent and smart (smart), and help them become better human beings (good). While Smucker in the journal Toto Suharto tried to approach education with the perspective of the community (community approach to education). He defines community as a collection of the population, lived in an adjacent region, integrated through a common experience, has a number of basic services institutions, aware of local unity, and able to act in his capacity as a corporation. The second is based on the above understanding of community-based education is one of the efforts to solve the problems of education.

Sihombing in the Fasli Jalal and Dedi Supriadi (2001:183188) confirmed there are five aspects, which became reference nonformal education in developing and implementing the concept of community-based education. First, technology that should be studied in accordance with the conditions and the real situation existing in society. The second is the institutional. The meaning is there should be a clear status container owned or borrowed, managed, developed by the community. Third is a social learning program, meaning that it must be a social value or must be meaningful to the lives of the learners or the citizens learn. Fourth are the ownership of the learning programs; institutional means should belong to the community, not the property of government agencies. Fifth are organization. The meaning is non-formal education authorities, meaning that it does not handle its own program, but rather a partner with society organizations.

\section{METHOD}

This research uses descriptive study towards nonformal education institutions. Data collection techniques used in this study consist of the study of documentation, study literature, study of primary data, and focus group discussion (FGD). The sample of this research is focused to the nonformal education institutional in West Java on the four regency or city, namely Bandung, West Bandung Regency, Sumedang and Cimahi. The data and information collected are qualitative information, statistical data, data persepsional which consists of a structured questionnaire and interviews, as well as open discussion groups focused.

\section{RESULT AND DISCUSSION}

Based on the results of question form from the agency managers say that they know the policy and regulation related to the conducting nonformal education program. The majority of them know one policy and regulation on the organization of nonformal education program, but they don't know how to implement the policy or regulation.

Edwards suggested in Haedar Akib's journal that without an effective implementation of policy decision makers will not succeed. Then the implementation of policy is an important part in policy decisions.

Non formal and informal education adopted by the Central Government from local governments had a wide range of regulations and policies to support the organization of education. However, in implementing the non formal education program experiencing various obstacles such as rules and regulations that are made merely noticed by the manager but not understood completely by the manager. This makes the non formal education program not organized like as appropriate. Supervisor as functional on duty to perform quality control and evaluation of non-formal and informal education services by monitoring non formal education programs so mentorship and coaching to educators and educational personnel in non formal education units of the individually. Based on the results now, the supervisor has been monitoring the non formal education programs in various of non formal education units but not done monitoring results are reported in the form of reports, and further construction is not done because of the limitations of their knowledge.

The majority belonged to non formal education institution's individuals who privately run group. Non formal education programmed itself has its diversity, ranging from Community Learning Center, A course of training institutions and Early-childhood education. Goal of nonformal education programs itself is a society from the middle to the bottom that has constraints specific to the following activities in formal education. The nonformal education agency was designed from, by and for the community so that the program is implemented based on the needs of the community. The presence of this fact, non formal education institutions can help mask the shortcomings of formal education, but many people who do not even know the existence of the non-formal education. This is a problem of its own because the conduct of non formal education that relies on citizen his study.

PNFI institution is an institution founded on the basis of education in society. Certainly PNFI agency referring to the five concept of administering education in community-based program proposed by SIH in Fasli Jalal and Dedi Supriadi (2001: 183-188). It is intended that the objectives of non-formal programs is getting more focused and have a clear reference to non-formal programs have a clear direction and systematic as in formal education.

\section{REFERENCES}

[1] Akib, Haedar (2010). "Implementation Of The Policy: What, Why, And How'. Journal Translation, Volume 1, No.1.ojs.unm.ac.id/index.php/iap/article/viewFile/289/6 (27 Nov 2015)

[2] Depdiknas (2003). RI Law No. 20 Of 2003 On The National Education System. Jakarta: Department Of National Education

[3] _ (2010). Government Regulation Number 17 In 2010 About The Management Of Education And The Organization Of Education. Jakarta; Department Of National Education

[4] (2013). Regulation Of The Minister Of Education And Culture Number 81 By 2013 On The Establishment Of Non-Formal Education Units. Jakarta: Department Of National Education

[5] (2013). Government Regulation No. 322013 About Education Standards. Jakarta: Department Of National Education 
[6] Jalal, F. \& Supriadi, D. (2001). Education Reform In The Context Of The Autonomy Of The Region. Yogyakarta: Adicita Nusa Works.

[7] Suharto, Toto (2005). Concept of Education Based On Society. Translation, Number 3

[8] Sudrajat, Ajat (2011). Why Character Education. Journal Translation. Number 1 